\title{
Acute Pancreatitis Associated with Rotavirus Infection and Review of The Literature
}

\author{
Rotavirüs Enfeksiyonuna Bağlı Akut Pankreatit Olguları ve Literatürün Gözden \\ Geçirilmesi
}

Kamil Şahin, (D) Güzide Doğan

University of Health Sciences, Haseki Training and Research Hospital, Department of Pediatrics, ístanbul, Turkey

\begin{abstract}
Agents causing acute gastroenteritis are not common causes of pancreatitis etiology in children. Pancreatitis associated with rotavirus infection is very rare. Cases with acute pancreatitis during rotavirus gastroenteritis are reported due to rare associations. In this article, the causes of acute pancreatitis and cases of acute pancreatitis due to rotavirus infection were investigated. Clinical findings were mild, and complications were not observed in both of our patients, including a twoyear-old female and a three-year-old male, and other cases evaluated in the literature. The patients were diagnosed with amylase-lipase elevation, imaging findings suggesting pancreatitis, and symptoms including vomiting and abdominal pain. The amylase and lipase levels of our patients decreased to normal levels in accordance with the literature, and no complication was observed in any patient. In the case of the continuation of abdominal pain in rotavirus gastroenteritis, it is essential to keep in mind the diagnosis of acute pancreatitis in terms of treatment and follow-up.
\end{abstract}

Keywords: Children, gastroenteritis, pancreatitis, rotavirus

\section{öZ}

Çocuklarda pankreatit etiyolojisinde akut gastroenterit etkenleri sık görülen sebeplerden değildir. Rotavirüs enfeksiyonuna bağlı görülen pankreatit ise oldukça nadirdir. Rotavirüs gastroenteriti sırasında akut pankreatit gelișen olgular, rotavirüs enfeksiyonuna bağlı akut pankreatitin nadir olması nedeniyle sunulmuştur. Bu yazıda, akut pankreatit sebepleri ve rotavirüse bağlı gelișen akut pankreatit olguları incelenmiștir. iki yaş kız ve üç yaşındaki erkek iki olgumuzda ve literatürde değerlendirilen diğer olgularda klinik bulgular hafif seyretmiş, komplikasyon görülmemiștir. Olgulara amilaz-lipaz yüksekliği, pankreatiti düşündüren görüntüleme bulguları ve kusma, karın ağrısı semptomlarıyla tanı konulmuştur. Olgularımızın amilaz ve lipaz değerleri literatür ile uyumlu günlerde normal seviyeye gerilemiş, hiçbir hastada komplikasyon gelişmemiştir. Rotavirüs gastroenteritinde karın ağrısının devamı halinde akut pankreatit tanısının akılda tutulması tedavi ve takip açısından önemlidir.

Anahtar Kelimeler: Çocuklar, gastroenterit, pankreatit, rotavirüs

\section{Introduction}

Rotavirus is the single most common and severe disease-causing cause of gastroenteritis under the age of 2 in the world. All children who have reached the age of 5 in the world have been infected with rotavirus at least once. The main symptoms of acute rotavirus gastroenteritis are fever, vomiting, watery diarrhea, abdominal cramps, and dehydration. Neither vaccine nor natural infection provides permanent immunity. The first natural infection progresses with very severe symptoms (1). Rotavirus infection is rarely seen among the causes of acute pancreatitis (2).

The annual incidence of pancreatitis in children in the United States is $13.2 / 100.000$ (3). The annual incidence of acute pancreatitis in childhood is reported to be 3.6-13.2/100.000 in different pediatric centers from Europe (4). In our country, there is not enough data on this issue (5). The incidence of pancreatitis in children has been increasing in recent years. The reason for this is that the frequency of diagnosis is increased depending on the awareness of the disease. Causes of acute pancreatitis in children differ from adults and often include drugs, infections, trauma, and anatomical disorders (6). In some cases, a cause cannot be determined (idiopathic pancreatitis) (7). Meeting at least two of the criteria determined for the diagnosis of acute pancreatitis is sufficient for diagnosis (8). Acute pancreatitis associated with rotavirus infection is extremely rare. In this article, it was aimed to present cases with acute pancreatitis due to rotavirus infection and to review the relevant
Address for Correspondence/Yazıșma Adresi: Kamil Şahin MD, University of Health Sciences, Haseki Training and Research Hospital, Department of Pediatrics, İstanbul, Turkey

Phone: +90 5324059706 E-mail: drkamil_sahin@hotmail.com ORCID ID: orcid.org/0000-0002-0443-2148

Cite this article as/Atıf: Șahin K, Doğan G. Acute Pancreatitis Associated with Rotavirus Infection and Review of The Literature. İstanbul Med J 2020; 21(1): 78-81.

(c) Copyright 2020 by the Istanbul Training and Research Hospital/istanbul Medical Journal published by Galenos Publishing House.

(C) Telif Hakkı 2020 istanbul Ĕgitim ve Araștırma Hastanesi/Istanbul Tıp Dergisi, Galenos Yayınevi tarafından basılmıștır.

Received/Geliș Tarihi: 17.05.2019 Accepted/Kabul Tarihi: 02.01.2020 
literature. We received written consent from the fathers of both of our cases for the case report.

\section{Case Reports}

\section{Case 1}

A two-year-old girl presented to the pediatric emergency clinic with fever for three days, watery, bloodless, mucous diarrhea, and vomiting ten times a day. There were mild fluid loss and tenderness in the epigastric region in the physical examination of the patient, who did not have any features in her medical history and family history. The patient's bowel sounds were increased, and other system examinations were normal. The patient had no trauma history or chronic disease in progress. Her laboratory results were as follows: leukocyte white blood cell (WBC): 8.230/ $\mathrm{mm}^{3}$, hemoglobin $(\mathrm{Hb}): 11.3 \mathrm{~g} / \mathrm{dL}$, platelet (PLT): 304.000/mm³ , urea: $13.3 \mathrm{mg} / \mathrm{dL}$, creatinine: $0.17 \mathrm{mg} / \mathrm{dL}$, sodium: 128 $\mathrm{mmol} / \mathrm{L}$, potassium: $2.8 \mathrm{mmol} / \mathrm{L}$, alanine aminotransferase (ALT): 10 $\mathrm{U} / \mathrm{L}$, aspartate aminotransferase (AST): $44 \mathrm{U} / \mathrm{L}$, total bilirubin: $0.2 \mathrm{mg} /$ $\mathrm{dL}$, direct bilirubin: $0.03 \mathrm{mg} / \mathrm{dL}$, and C-reactive protein (CRP): $3.8 \mathrm{mg} / \mathrm{L}$ (range: 0-5). The microscopic examination of stool was normal, the rotavirus antigen was positive in stool, and there was no pathological growth in stool culture. On the third day of hospital stay, the amylase value was $122 \mathrm{U} / \mathrm{L}$ (28-100), and lipase value was $280 \mathrm{U} / \mathrm{L}$ (5-31), which were evaluated due to continuation of vomiting, abdominal pain, and tenderness in the epigastric region. The pancreas was edematous in abdominal ultrasonography (USG). Acute pancreatitis was considered in the patient, and other tests for the etiology of acute pancreatitis were negative. Oral intake was stopped. Intravenous (IV) fluid and ranitidine treatment were started. In the follow-up, the amylase and lipase values decreased to normal on the eighth day of the treatment, and the patient did not develop any complications and was discharged upon the remission of her findings.

\section{Case 2}

A three-year-old male patient presented with vomiting and watery diarrhea for five days. There was no feature in his medical history and family history. On physical examination, the tongue was dry, the turgor was impaired, and there were signs of moderate fluid loss. Intestinal sounds were increased, and there was widespread tenderness in the epigastric region and lower abdominal quadrants. There was no abdominal defense and rebound. His laboratory results were as follows: WBC: $20.720 / \mathrm{mm}^{3}$, Hb: $12 \mathrm{~g} / \mathrm{dL}$, PLT: 502.000/mm³ , urea: $38 \mathrm{mg} / \mathrm{dL}$, creatinine: $0.23 \mathrm{mg} / \mathrm{dL}$, sodium: $136 \mathrm{mmol} / \mathrm{L}$, potassium: $4.1 \mathrm{mmol} / \mathrm{L}$, ALT: $30 \mathrm{U} / \mathrm{L}, \mathrm{AST}$ : $50 \mathrm{U} / \mathrm{L}$, total bilirubin: $0.22 \mathrm{mg} / \mathrm{dL}$, direct bilirubin: $0.06 \mathrm{mg} / \mathrm{dL}$, and CRP: $4.4 \mathrm{mg} / \mathrm{L}$ (range: 0-5). Rare leukocyte and rotavirus antigen positivity were detected in the microscopic examination of stool, and there was no pathological growth in stool culture. The pancreas was found to be heterogeneous in abdominal USG performed due to extensive tenderness in the abdomen. The amylase level was $108 \mathrm{U} / \mathrm{L}$ (range: 28-100), and lipase was $288 \mathrm{U} / \mathrm{L}$ (range: 5-31). No other factor was found in the examinations for the cause of acute pancreatitis. Acute pancreatitis due to rotavirus infection was considered in the patient. The enteral feeding of the patient was stopped, and IV fluid treatment was started. His clinical findings improved, and amylase and lipase levels decreased gradually during follow-up, and he was discharged on the tenth day of diarrhea. It was found that the amylase and lipase levels observed on the $12^{\text {th }}$ day of control were normal.

\section{Discussion}

Rotavirus is a cause of diarrhea with high morbidity and mortality all over the world. While diarrhea, vomiting, and fever are common in this viral enteritis, abdominal pain is a rare finding. Acute pancreatitis has broad findings from mild abdominal pain to severe metabolic disorder and shock (9). The diagnosis of acute pancreatitis is determined by providing at least two of the three criteria including a) abdominal pain that is more prominent in the epigastric region, that can be seen in the right and left upper quadrants, and that rarely spreads to backward, unlike in the adult, b) more than three-fold increase in serum amylase and/or lipase levels, and c) radiological imaging findings of pancreatitis (Table 1) $(8,10)$. Causes of acute pancreatitis in children differ from adults. Causes in children are generally drugs, infections, trauma, and anatomical disorders (Table 2) (4). Apart from these reasons, the cause cannot be found in $23 \%$ of the cases (7). While the sensitivity of USG, which is one of the imaging methods that support pancreatitis, is $70 \%$, the sensitivity of computed tomography is $90 \%$ (11). Magnetic resonance cholangiopancreatography, on the other hand, is a noninvasive method that has superiority even to endoscopic retrograde cholangiopancreatography since it can easily show anatomical disorders

Table 1. Acute pancreatitis diagnostic criteria (6)

Having at least two of the three criteria below;

1. Abdominal pain compatible with acute pancreatitis,

2. Serum amylase and/or lipase levels three times higher than than the upper limit of normal

3. Detection of findings supporting pancreatitis in radiological examinations (ultrasonography, magnetic resonance imaging, or computed tomography).

\section{Table 2. Causes of acute pancreatitis in children (4)}

1. Congenital anomalies and obstruction around the bulb: Choledochal cysts, pancreaticobiliary junction anomalies, gallstones, cholecystitis, pancreatic divisum, tumors, congestion due to Ascaris parasite,

2. Infections: Mumps, measles, Coxsackie, Echovirus, influenza, Epstein-Barr viruses, and Mycoplasma, Salmonella, Gram-negative bacteria

3. Drugs: L-asparaginase, steroid, valproic acid, azathioprine, mercaptopurine, mesalazine, cytarabine, salicylic acid, indomethacin, tetracycline, chlorothiazide, isoniazid, anticoagulant drugs, alcohol,

4. Trauma: Blunt trauma, child abuse, ERCP and post-surgery,

5. Systemic diseases: Reye's syndrome, Systemic Lupus Erythematosus, Polyarteritis Nodosa, Juvenile Rheumatoid Arthritis, Sepsis, Multiple Organ Failures, Organ Transplants, Hemolytic Uremic syndrome, Henoch Schoenlein purpura, Kawasaki disease, Inflammatory Bowel disease, Chronic Intestinal Pseudo-obstruction, Gastric Ulcers, Anorexia Nervosa, Drug Allergies, Cystic Fibrosis,

6. Metabolic causes: Hyperlipoproteinemia (I, IV, V), hypercalcemia, diabetes, $\alpha 1$ antitrypsin deficiency,

7. Nutritional disorders: Malnutrition, high-calorie infusion, vitamin A and D deficiency,

8. Other reasons: Familial, idiopathic.

ERCP: Endoscopic retrograde cholangiopancreatography 
and stone possibilities (3). Although there is not an absolute value in determining the severity of pancreatitis, a more than seven-fold increase in serum lipase is one of the crucial indicators of severity and has a sensitivity of $85-90 \%$ (12). There may be recurrences in $15-35 \%$ of acute pancreatitis cases. Acute recurrent pancreatitis is mostly due to causes such as idiopathic, genetic mutations, and biliary anomalies (13). The risk of death from this disease in children ranges from $0-11 \%$ and is lower than in adults (14).

The diagnosis of acute pancreatitis is difficult due to its rarity and heterogeneous findings. Severe pancreatitis develops less frequently in children than in adults. Although hyperamylasemia has been reported with some infectious agents after acute gastroenteritis, acute pancreatitis is rare (15). In their study, Tositti et al. (16) evaluated 507 adult gastroenteritis patients and showed that $10.2 \%$ of cases had hyperamylasemia, and only one case developed acute pancreatitis. It has been reported that hyperamylasemia is seen mostly in gastroenteritis due to Salmonella species, followed by rotavirus, Clostridium difficile, and Campylobacter species. However, acute pancreatitis was not detected in any adult case with rotavirus gastroenteritis $(n=29)$ in this series (16). Retrospective studies state that adults with gastroenteritis have a temporary hyperamylasemia but that this is not pancreatitis (2).

In the article in which 87 children with acute pancreatitis were evaluated in our country, the most common complaints were sudden onset abdominal pain in $79 \%$ patients, vomiting in 12\% patients, and restlessness in $6 \%$ patients. No complaints were detected in one patient, and the diagnosis was reported to be made with elevated amylase and lipase values and radiological findings. While a cause could not be determined in $25 \%$ of these patients, the most common cause was trauma. Infection was not detected among the causes. Recurrence occurred in $15 \%$ of patients, and only one patient progressed to chronic pancreatitis. Four patients died due to this disease (17).

In experimental studies in newborn mice, rotavirus has been shown to replicate in the liver, spleen, pancreas, heart, thymus, lungs, and kidneys. Histopathological changes are caused by rotavirus and include inflammation of the portal system and biliary tract (18). Nuclear Factor B (NF-B) is activated with the effect of interleukin 8 (IL-8), which is chemotactic in rotavirus infection (19). The main destructive effect in rotavirus infection is due to the inflammation caused by neutrophils, macrophages, lymphocytes, and monocytes, rather than the cytopathic virus effect, which are attracted to the environment with the effect of IL-8 (19). IL-8 is used in the clinic to distinguish rotavirus gastroenteritis from other gastroenteritis (20). IL-8 may also be the factor that initiates rotavirus pancreatitis. In the literature, it has been mentioned that measuring and monitoring serum IL-8 levels is the correct method for following prolongation and chronicization of pancreatitis (21). Recovery of rotavirus gastroenteritis is related to virus-specific interferon-gamma formation (15). Interferon-gamma plays a vital role in the control of viral infections. Interferon-gamma also protects from pancreatitis. It does this by reducing NF-B and IL-8 (22).

In order to be able to diagnose acute pancreatitis due to rotavirus infection, the causes that may have a role in etiology and which we mentioned in Table 2 should be investigated (6). In our cases, other causes of acute pancreatitis were excluded. Acute pancreatitis due to rotavirus infection has a good prognosis, and no complication develops in this pancreatitis. In cases in the literature, amylase and lipase levels returned to normal within 5-12 days (23). In accordance with the literature, our cases also had an excellent course, and the amylase and lipase levels returned to normal on the $8^{\text {th }}$ and $12^{\text {th }}$ days.

The first rotavirus pancreatitis was published in 2009 in India (24). Considering that rotavirus infection is widespread in the world, it can be thought that there are many cases with pancreatitis that are overlooked in young infants. In a school-age patient reported from our country, it was recently reported that rotavirus-induced pancreatitis was observed after a prolonged abdominal pain complaint (8). In the case reports of 2.5- and 3-year-old patients with diagnosed rotavirus gastroenteritis in our country, lipase levels were found twice and five times higher than the amylase levels and abdominal ultrasonographic examinations were found to be normal. On the $12^{\text {th }}$ and $13^{\text {th }}$ days, amylase and lipase levels returned to normal, and patients recovered without complications (25). In a publication from our country in 2018 , seven cases reported in the literature were mentioned. It was observed that all of the cases had diarrhea, vomiting, abdominal pain, and the majority of the cases were between two and five years old. Our cases are also compatible with the literature regarding age groups. In half of the cases, a slightly enlarged pancreatic appearance was detected in the radiological evaluations. IV hydration or IV hydration + ranitidine treatment were given as treatment (23). We administered IV hydration plus ranitidine treatment to our case with more pronounced epigastric pain, and IV hydration treatment to our other case. After the case reports in 2018, we have not encountered any recently reported cases in the literature. The reason for not being encountered maybe since abdominal pain is considered as the prolonged symptom of gastroenteritis and that amylase and lipase levels are not examined, and mild pancreatitis improves without being diagnosed.

In conclusion, rotavirus-induced pancreatitis should be considered among the cause of abdominal pain in rotavirus gastroenteritis, which is common in children, and this should be kept in mind in terms of treatment approach and follow-up.

Informed Consent: We received written consent from the fathers of both of our cases for the case report.

Peer-review: Externally peer-reviewed.

Author Contributions: Surgical and Medical Practices - K.Ş., G.D.; Concept - G.D.; Design - K.Ş., G.D.; Data Collection and/or Processing K.S., G.D.; Analysis and/ or Interpretation - K.Ş.; Literature Search - K.Ş., G.D.; Writing Manuscript - K.S.

Conflict of Interest: No conflict of interest was declared by the authors

Financial Disclosure: The authors declared that this study received no financial support.

\section{References}

1. Tate JE, Burton AH, Boschi-Pinto C, Steele AD, Duque J, Parashar UD; WHOcoordinated Global Rotavirus Surveillance Network. 2008 estimate of 
worldwide rotavirus-associated mortality in children younger than 5 years before the introduction of universal rotavirus vaccination programmes: a systematic review and meta-analysis. Lancet Infect Dis 2012; 12: 136-41.

2. Parri N, Innocenti L, Collini S, Bechi F, Mannelli F. Acute pancreatitis due to rotavirus gastroenteritis in a child. Pediatr Emerg Care 2010; 26: 592-3.

3. Shukla-Udawatta M, Madani S, Kamat D. An Update on Pediatric Pancreatitis. Pediatr Ann 2017; 46: 207-11.

4. Cole S, Wakeham M, Werlin S, Goday PS. Classification and nutrition management of acute pancreatitis in the pediatric intensive care unit. J Pediatr Gastroenterol Nutr 2018; 67: 755-9.

5. Urgancı N. Çocuklarda akut pankreatite yaklașım. Güncel Gastroenteroloji 2019; 23: 90-6.

6. Suzuki M, Sai JK, Shimizu T. Acute pancreatitis in children and adolescents. World J Gastrointest Pathophysiol 2014; 5 :416-26.

7. Benifla M, Weizman Z. Acute pancreatitis in childhood: Analysis of literature data. J Clin Gastroenterol 2003; 37: 169-72.

8. Emiroğlu HH. Rotavirus infeksiyonuna bağlı seyrek görülen bir tutulum: Akut pankreatit. J Contemp Med 2018; 8: 85-6.

9. Lautz TB, Chin AC, Radhakrishnan J. Acute pancreatitis in children: spectrum of disease and predictors of severity. J Pediatr Surg 2011; 46: 1144-9.

10. Fabre A, Petit P, Gaudart J, Mas E, Vial J, Olives JP, et al. Severity scores in children with acute pancreatitis. Pediatr Gastroenterol Nutr 2012; 55: 266-7.

11. Pant C, Deshpande A, Olyaee M, Anderson MP, Bitar A, Steele MI, et al. Epidemiology of acute pancreatitis in hospitalized children in the United States from 2000-2009. PLoS One 2014; 9.

12. Coffey MJ, Nightingale S, Ooi CY. Serum lipase as an early predictor of severity in pediatric acute pancreatitis. J Pediatr Gastroenterol Nutr 2013; 56: 602-8.

13. Aksu AÜ, Sarı S, Gürkan ÖE, Dalgıç B. Türk çocuklarda pankreatit: Tek merkez deneyimi. Cukurova Med J 2019; 44: 991-8.

14. Bai HX, Lowe ME, Husain $\mathrm{S}$. What have we learned about acute pancreatitis in children? J Pediatr Gastroenterol Nutr 2011; 52: 262-70.

15. Yuan L, Wen K, Azevedo MS, Gonzalez AM, Zhang W, Saif LJ. Virus-specific intestinal IFN-gamma producing $T$ cell responses induced by human rota virus infection and vaccines ar ecorrelated with protection against rotavirus diarrhea in gnotobiotic pigs. Vaccine 2008; 26: 3322-31.

16. Tositti G, Fabris P, Barnes E, Furlan F, Franzetti M, Stecca C, et al. Pancreatic hyperamylasemia during acute gastroenteritis: Incidence and clinical relevance. BMC Infect Dis 2001; 1: 18.

17. Sağ E, Kaya G, Bahat-Özdoğan E, Karahan SC, İmamoğlu M, Sarıhan H, at al. Acute pancreatitis in children: A single center experience over ten years. The Turkish Journal of Pediatrics 2018; 60: 153-8.

18. Crawford SE, Patel DG, Cheng E, Berkova Z, Hyser JM, Ciarlet M, et al. Rotavirus viremia and extraintestinal viral infection in the neonatal rat model. J Virol 2006; 80: 4820-32.

19. Casola A, Garofalo RP, Crawford SE, Estes MK, Mercurio F, Crowe SE, et al. Interleukin-8 gene regulation in intestinal epithelial cells infected with rotavirus: Role of viral-induced I kappa B kinase activation. Virology 2002; 298: 8-19.

20. Chen SM, Lin CP, Tsai JD, Chao YH, Sheu JN. The significance of serum and fecal levels of interleukin-6 and interleukin-8 in hospitalized children with acute rotavirus and norovirus gastroenteritis. Pediatr Neonatol 2014; 55: 120-6.

21. Digalakis MK, Katsoulis IE, Biliri K, Themeli-Digalaki K. Serum profiles of C-reactive protein, interleukin-8, and tumor necrosis factor-alpha in patients with acute pancreatitis. HPB Surg 2009; 2009: 878490.

22. Hayashi T, Ishida Y, Kimura A, Iwakura Y, Mukaida N, Kondo T. IFN-gamma protects cerulein-induced acute pancreatitis by repressing NF-kappa B activation. J Immunol 2007; 178: 7385-94.

23. Karadă̆ Öncel E, Yılmaz Çiftdoğan D, Vardı K, Baran M. Rotavirüs gastroenteritine ikincil gelișen akut pankreatit: Bir olgu sunumu ve literatürün gözden geçirilmesi. Pediatr Inf 2018; 12: 25-9.

24. Kumagai H, Matsumoto S, Ebashi M, Ohsone T. Acute pancreatitis associated with rotavirus infection. Indian Pediatr 2009; 46: 1099-101.

25. Cay P, Elif Uzlu S, Esra Yilmaz A, Bakan V. Acute pancreatitis: A rare but important complication of rotavirus gastroenteritis in children. Minerva Pediatr 2014; 66: 587-8. 